\title{
SITUATED LEARNING AND PROFESSIONAL DEVELOPMENT: A CASE STUDY OF APPLYING COGNITIVE APPRENTICESHIP AND COMMUNITY OF PRACTICES IN A KINDERGARTEN
}

\author{
Ching-Ching Cheng \\ Providence University, Taiwan \\ E-mail: cccheng@pu.edu.tw
}

\begin{abstract}
The purpose of this study is to implement and evaluate a teacher training program based on the framework of situated learning. Adapting from the situated learning approaches, the author implemented two in-service teacher training programs based on cognitive apprenticeship and community of practices respectively. Each training program was adopted in a different campus of a private kindergarten. During the six-month training, researcher conducted a qualitative research to evaluate the effectiveness of the training program. To investigate how teachers improved their professional skills in constructive instruction, the researcher invited four supervisors and 10 kindergarten teachers to participate in the training program. The qualitative data included classroom observation, focus group, interviews, and teachers' reflection notes. The results suggest that both programs may aid learning of engaging in constructivist instruction by providing external supports such as model instruction plans, mentoring, cooperating to solve problems. Nevertheless, the relationship or power hierarchy between mentors and learners is important in cultivating mentees' capabilities. Practices sharing in community of practices approach, rather than supervisors' expertise and diagnosis, will help the mentees to enhance their capabilities of solving problems.
\end{abstract}

Key words: cognitive apprenticeship, community of practices, kindergarten teacher, professional development, situated learning, teacher training.

\section{Introduction}

In recent years, the inquiry-based learning curriculum and the project-approach curriculum have been gaining more attention in Taiwan. Contrary to the teacher-dominated or textbookoriented curriculum, the inquiry-based leaning or the project-based curriculum emphasizes on flexible and dynamic arrangement of activities. To adaptively lead children's learning activities, teachers have to monitor the curriculum development and children's learning status simultaneously. Under these conditions, teachers' curriculum developing ability is crucial in insuring the learning quality. Therefore, how to encourage in-service teachers to engage in constructivist instruction becomes critical to the success of curriculum reform. Among the accumulated prior researches in teacher education, situated learning provides an environment inviting senior and novice teachers to share their experiences, exchange knowledge, and thus facilitate professional development. The purpose of this study is to implement and evaluate a teacher training program based on the framework of situated learning. Adapting from the situated learning approaches, the researcher implements two in-service teacher training programs based on cognitive apprenticeship and community of practices respectively. 
Ching-Ching CHENG. Situated Learning and Professional Development: A Case Study of Applying Cognitive Apprenticeship and Community of Practices in a Kindergarten

PROBLEMS

OF EDUCATION

IN THE $21^{\text {st }}$ CENTURY

Volume 59, 2014

The purpose of this research is to investigate how the framework of situated learning can be implemented in professional development for kindergarten teachers. Among the two case studies, the first is an interpretative study that examines these teachers' strategies, problems, needs, and motivational orientations after adopting cognitive apprenticeship. The cognitive apprenticeship approach includes assigning exemplar lesson plans and periodical mentoring by a supervisor during instruction. The focus is on instruction improvement in the constructivist learning environment. In the second study, the effectiveness of professional development was explored by adopting the approach of 'community of practices' which was formed to help one another to solve problems in teaching practices.

\section{Literature Review}

According to Barab, Squire, and Dueber (2000), two common designs would help students to learn in context. The first design is a simulation model, which emphasizes that classroom activities should be developed to be as similar as possible to practice in professional communities outside of school. The second design is a participation model, which places emphasis on helping students to engage in authentic practices as part of a community by immersing students into the actual communities as peripheral participation (Barab et al., 2000). The difference between two models is "the interaction of the planned and the emergent" (Wenger, 1998, p. 267). There are varieties of tacit knowledge and accidental events of learning during participation of community of practices. In addition to the curriculum goals, the educational design should provide an authentic learning environment while matching educational goals, but capturing the essence of practices in the community, particularly in professional development (Wenger, 1998).

Although grounding on the contextual learning during completion of authentic tasks, cognitive apprenticeship and community of practices differ in term of purpose, members, attraction, and duration (Wenger \& Snyder, 2000). In professional development for early childhood staff, mentoring has expanded into a variety of models. In US tradition, the mentor, typically in a higher position will coach, protect, arrange challenging tasks, and help the mentee to meet important people (Kram, 1985). In European tradition, the mentor is often more experienced than the mentee, not necessarily in supervisory position. The mentor's tasks include helping the mentee to have a wider view or find the needed solutions. The mutuality of learning between the mentor and mentee is emphasized (Megginson, Clutterbuck, Garvey, Stokes, \& Gareet-Harris, 2006). As shown in Table 1, the US model is similar to the cognitive apprenticeship model while the European model is similar to community of practices.

Table 1. A comparison of cognitive apprenticeship and community of practices.

\begin{tabular}{lllll}
\hline & Purpose & Participants & Attraction & Duration \\
\hline $\begin{array}{l}\text { Cognitive ap- } \\
\text { prenticeship }\end{array}$ & $\begin{array}{l}\text { To develop } \\
\text { mentee's cognitive } \\
\text { abilities }\end{array}$ & Mentor and mentee & Learners' needs & $\begin{array}{l}\text { Until the learner is } \\
\text { competent }\end{array}$ \\
\hline $\begin{array}{l}\text { Community of } \\
\text { practices }\end{array}$ & $\begin{array}{l}\text { To develop mem- } \\
\text { bers' capabilities }\end{array}$ & $\begin{array}{l}\text { Members who select } \\
\text { themselves }\end{array}$ & $\begin{array}{l}\text { Passion, commitment, } \\
\text { and identification }\end{array}$ & $\begin{array}{l}\text { As long as there is an } \\
\text { interest in maintaining } \\
\text { the group }\end{array}$ \\
\hline
\end{tabular}




\section{Cognitive Apprenticeship}

Cognitive apprenticeship, emphasizing on learning is embedded in activities, is an approach which makes deliberate use of social and physical context (Collins, Brown, \& Newman, 1989; Resnick, 1987). The design of practice fields has been proposed as approaches similar to problem-based learning, in conjunction with anchored instruction and cognitive apprenticeship to conceptualize learning in practice (Huang, 2011). Consistent with the concept of authentic activities, learners will work in teams that contend with problems from the industry (Barab \& Duffy, 2000; Brown \& Duguid, 1996; Dunlap, 2005). Educators usually simulate practice fields by identifying what is to be learned in real-world situations, and conduct these authentic activities within the surrounding environments. The principles used in simulation model include conducting domain-related practices, ownership of inquiry, and collaborative and social work (Barab \& Duffy, 2000). Cognitive apprenticeship will shape the learning interaction from teacher-oriented instruction to joint goal-oriented problem-solving between teacher and student (Jarvela, 1995).

Intentional teaching and learning through cognitive apprenticeship requires making tacit processes visible to learners so that they can observe and then practice them (Collins et al., 1989). Gallimore and Tharp (1990) identified instructing, questioning, modeling, feeding back, cognitive structuring, and contingency management as six forms of scaffolded assistance. The cognitive apprenticeship approach is also used to support teacher education by providing preservice teachers with guidance, as well as engaging learners in different types of practice until the guidance is no longer needed.

\section{Community of Practices}

What is community of practices? It is a group of people informally bound together by shared expertise and passion for a joint enterprise. A community has a core of participants whose passion for the topic energizes the community and who provide intellectual and social leadership. As Wenger (1998) argued, the curriculum is the community of practice itself, and learning is a meaning-making activity inherent in the activity of the community. Therefore, the development of knowledgeable skills and identity in the community of practices are not two separate processes (Lave, 1993; Lave \& Wenger, 1991). Through participating in community activities, students will develop "self" during the engagement.

In spite of successful cases of problem solving, communities of practices are vulnerable in industry because they lack the legitimacy and the budgets of established departments. To reach the full potential, then, they need to be integrated into the business and supported in specific ways (Wenger \& Snyder, 2000). First, senior executive must be prepared to invest time and money in helping such communities reach their full potential. Second, provide them with official sponsors and support teams.

The applications of the community of practices framework on teacher education can be examined across key dimensions such as diverse membership, goals, and participatory framework (Buysse, Sparkman, \& Wesley, 2003). Bell and Gilbert (1996) claim that teachers will undergo social, personal, and professional development within the context of a teacher-development program that includes support, feedback, and reflection. It is community of practices to establish a learning community across levels of expertise rather than within them and provide the learners with models of collaborative inquiry. It offers perhaps the greatest promise in terms of achieving diverse expertise and making an impact on the field, because the approach recognizes the many concerns related to belief, cultures, tacit knowledge, identity, and power that do not fall neatly into disciplines (Wesley \& Buysse, 2001). 
Ching-Ching CHENG. Situated Learning and Professional Development: A Case Study of Applying Cognitive Apprenticeship and Community of Practices in a Kindergarten

PROBLEMS

OF EDUCATION

IN THE $21^{\text {st }}$ CENTURY

Volume 59, 2014

\section{Methodology of Research}

\section{General Background of Research}

To understand the effectiveness of a teacher training program based on the framework of situated learning. The researcher implemented two situated-learning-oriented teacher training programs based on cognitive apprenticeship and community of practices respectively. By comparing the two studies of teacher training programs, adopting different approaches, the case studies under natural contexts would provide an insightful understanding of teachers' development in the authentic environments.

\section{Data Collection and Analysis}

To model a better teacher training program for a private kindergarten, which is wellknown for the successful implementation of constructivist instruction activities in Taiwan, the researcher first implemented a teacher training program based on the cognitive apprenticeship model and community of practices model respectively. Each training program was adopted in a different campus for a semester. During the six-month training, researcher conducted a qualitative research to evaluate the effectiveness of the training program. To investigate how teachers improved their professional skills in constructive instruction, the researcher invited four supervisors and 10 kindergarten teachers to participate in the training program. The qualitative data included classroom observation, focus group, interviews, and teachers' reflection notes.

\section{Study 1: Cognitive Apprenticeship}

The cognitive apprenticeship approach was implemented as modeling and monitoring. A supervisor, also a senior teacher who was familiar with constructivist instruction, served as the mentor. Teachers who to be trained on constructivist instruction were mentees. As in Figure 1 , the training program was divided into three phases, namely diagnosis, integration, and revision.

At first, the supervisor who well understood each teacher's abilities and instruction discussed with the mentees on their needs and curriculum plans individually. Then, the supervisor and the mentees formed a study group to read and discuss the exemplar lesson plans periodically. Theses constructivist lesson plans were real cases of successfully instructed. For example, projects of constructing marble platforms, bridges, or houses in the block building area, measuring activities, as well as science processes and concept exploration. These lesson plans included documents of starting of the curriculum, children's performance during exploration, teachers' arrangement of environment and resources, leading of the curriculum, and the results or artifacts of exploration. After evaluation and diagnosis, the supervisor selected certain lesson plan for individual teachers to model.

In the second phase, exemplar lesson plans were used as model curriculum for mentees to integrate into their classes. After reading the assigned lesson plan, the mentee tried to grasp and integrate the essence of model curriculum into instruction activities.

Finally, during instruction activities, the supervisor regularly observed instruction and discussed with the mentees. As a mentor, the supervisor would propose suggestions to revise some instruction activities. 


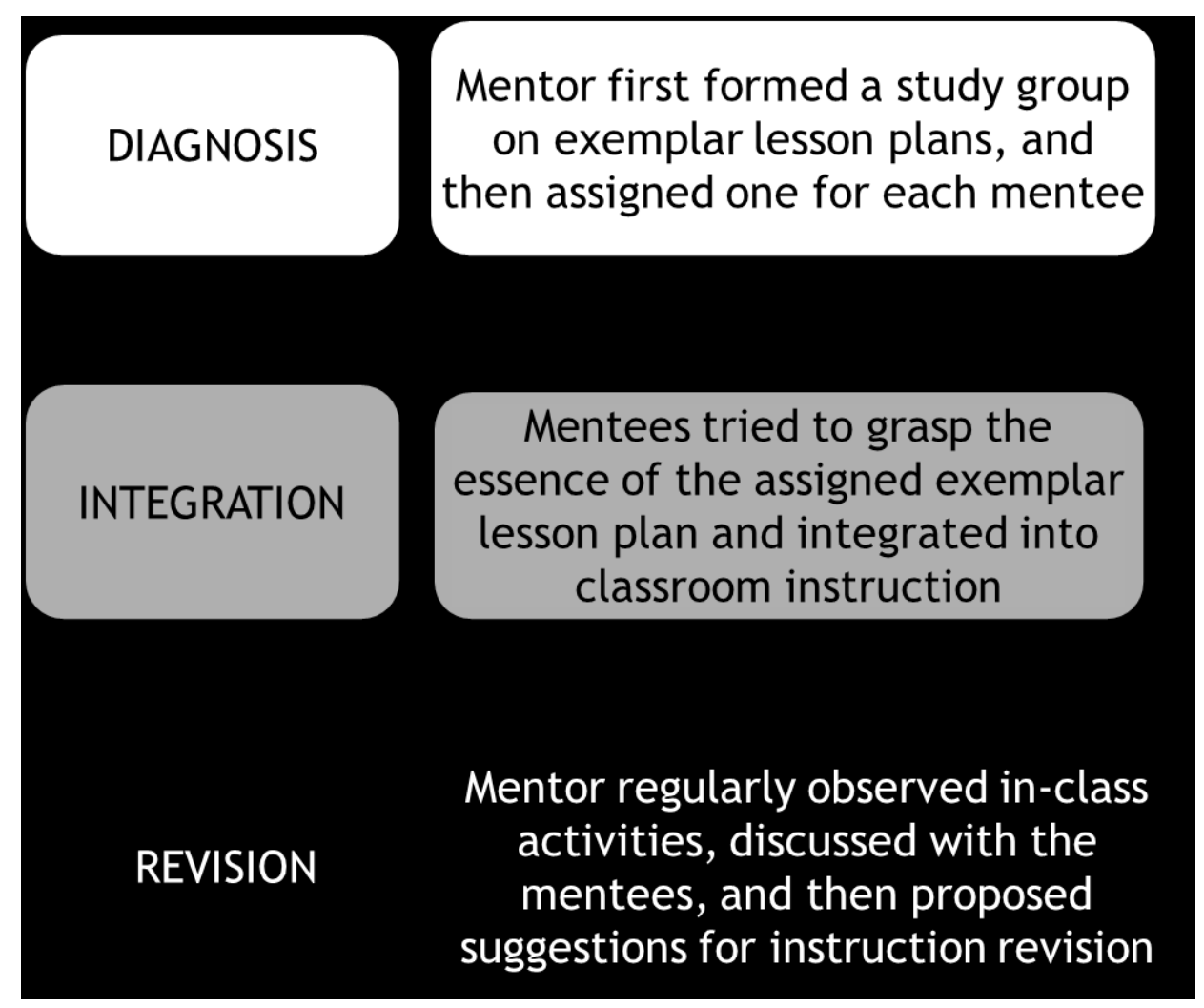

PROBLEMS

OF EDUCATION

IN THE $21^{\text {st }}$ CENTURY

Volume 59, 2014

Figure 1: Three phases of modeling in cognitive apprenticeship.

\section{Study 2: Community of Practices}

To create a practice-sharing environment for teacher professional development, the community of practices model was adopted. An instruction-discussion group, consisted of 12 teachers and 2 supervisors, was formed to develop members' professional capabilities by solving problems encountered during instruction. The duration of this study lasted for 5 months. Data collection consisted of interviews and documents such as group meeting record, children's artifacts, as well as documentation on curriculum.

The activities of the training program included describing personal teaching difficulties, group discussion, identifying problems, finding key elements, proposing strategies and reviewing outcomes, and solving on-site curriculum developing problems.

At the meetings, some teachers reported problems in instruction. And then group members discussed to clarify the contexts and list hypothesis. For example, a teacher mentioned the distraction of children during inquiry activities. She contributed to the failure of continuing exploration to teacher's insufficient skills for leading group discussion (see Figure 2). During the next meeting, group members gathered in the classroom to observe the learning activities. Then, a group meeting was held to discuss the reasons and propose possible solutions. In the end, the teacher regularly reported the changes in the classroom afterward. 
CATION

OF EDUCATION

IN THE $21^{\text {st }}$ CENTURY

Volume 59,2014

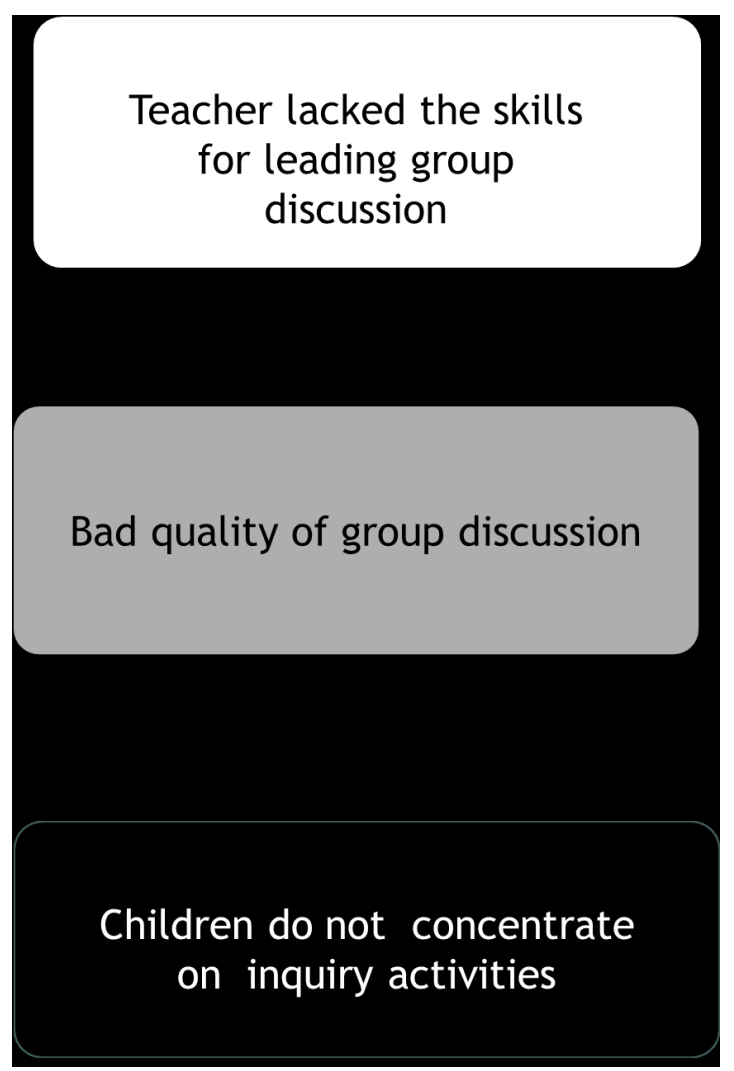

Figure 2: A teacher initially proposed solutions on the instruction barrier.

\section{Results of Research}

\section{Changes with Cognitive Apprenticeship}

The findings indicated that teachers improved themselves in constructivist teaching. However, the teachers performed differently because of variety of instruction capabilities. For teachers with less experience or professional capabilities, they tended to copy the teaching procedures, dispatch tasks to children and reach the similar goals of the curriculum. On the contrary, their intervention resulted in teacher-dominant learning activities, which mismatched the constructive learning of theme-based curriculum. The supervisors revealed in the interviews: 'some teachers just copied the given lesson plans disregarding children's response,' as well as 'some teachers initially inspired children to engage in projects, however, they could not continue to motivate and lead children to further explore'.

This top-down training model provides contextual learning supports to help teachers to develop themselves professional skills. The resources include exemplar lesson plans and supervisors' mentoring. In the pair-wise cognitive mentorship, the mentor did not have time to assess teachers' needs and give appropriate suggestions in time. During regular in-class observation and discussion, the supervisors seldom intervened to change teachers' instruction unless teachers actively asked for suggestions. Owing to the hierarchical relationship, teachers made efforts to show the positive sides rather than present the barriers in instruction. 


\section{Changes with Community of Practices}

$\mid$\begin{tabular}{l} 
PROBLEMS \\
OF EDUCATION \\
IN THE 21 $1^{\text {st }}$ CENTURY \\
Volume 59, 2014 \\
\hline 21
\end{tabular}

This community of practices provides opportunities of exchange knowledge; therefore, teachers help one another to solve problems of instruction. Nevertheless, after rounds of meeting and in-class observation, the group found out the teacher needed to improve self in planning about team teaching, leading group discussion, and use the resources provided by the staff. As Figure 3 showed, the community, after clarification and brainstorming, re-depicted the reasons and possible solutions. They revised the original hypothesis proposed by the teacher as shown in Figure 2.

During the group activities, participants start to think critically and reason about curriculum content. Increasing their knowledge of theories and practices, they learn to change their role from being the center of attention and resource of all knowledge to being the facilitator for the acquisition of that knowledge. To evaluate the impacts of this program on the teachers' abilities in curriculum development, researcher interviews participating teachers during and after this program. The results indicate that this program not only improves teachers' curriculum developing ability and reflective thinking, but also facilitates cooperation among staff.

\section{Differences between Two Approaches}

Although both programs facilitate teachers' professional development, there are several differences in terms of help seeking, learning atmosphere, adaption, and supports.

First, power hierarchy influenced willingness of help seeking. The structure or power hierarchy resulted in differences of motivation. The cognitive apprenticeship is a top-down structure. With superior expertise, experience, or power, the supervisor directed the mentees' professional development by assigning exemplar instruction plan and monitoring their learning from modeling. To positively impress the mentor, mentees were not willing to actively state their problems or difficulties during adopting the exemplar lesson plans. In a community of practices, solving instructional problems in practical fields became the main concern. Mentees seemed more willing to express their difficulties and solicitation for improvement suggestions.

Second, distributed cognition changed learning atmosphere. In cognitive apprenticeship approach, the mentees were motivated to meet mentor's expectation because the supervisor serving as the mentor who owned the power to evaluate teachers' performance. The benefit is the mentees will tend to follow supervisor's suggestions and make efforts to perform well. However, the authority also made the novice teacher rely on supervisor's direction, instead of questioning suggestions or testing own ideas. On the contrary, members of community of practices are mentors and mentees at the same time. In a community of practices, novice teachers could state their encountering instruction problems and ask for suggestions. Group members are equal in proposing possible solutions based on their expertise or experiences. Therefore, mentees had the freedom to debate, clarify, accept, revise, or reject solutions.

Third, flexible schedule brought out adaption. Because of official schedule for mentoring in the cognitive apprenticeship model, mentors could not flexibly spend more time on mentees in needs. Most of the mentoring activities were arranged in school time. In fact, the mentors admitted that they were able to interact with each mentee within time slots and provide suggestions based on their observation and judgment. For those progressing limitedly, they barely gave more time. Community of practices is an informal learning network, so group members can decide the time, location and forms of activities. For example, lunch or after school time was frequently used to share their practices. In addition, the gatherings could be continued even if some members were absent.

Last, diversity of expertise encouraged mutual-supports. In cognitive apprenticeship approach, the supervisor regularly monitored and mentored teachers' instruction on one-to-one 
Ching-Ching CHENG. Situated Learning and Professional Development: A Case Study of Applying Cognitive Apprenticeship and Community of Practices in a Kindergarten

PROBLEMS

OF EDUCATION

IN THE $21^{\text {st }}$ CENTURY

Volume 59, 2014

basis. Nevertheless, their interaction was limited to pair so that the mentee obtained much less supports from peers than community of practices. As prior studies confirmed that the supports and inspiration from the peer group would help to improve novice teachers' instruction (Cohan \& Honigsfeld, 2011; Hoban, 2005). In community of practices, mentees were motivated to solve their problems in practices. To help solve the problems, group members would propose possible solutions based on their expertise or experiences. In addition to the supervisors, senior teachers, or even novice teachers with similar experiences, could give comments or advices. Meanwhile, everyone was motivated to learn by either contributing or receiving suggestions.

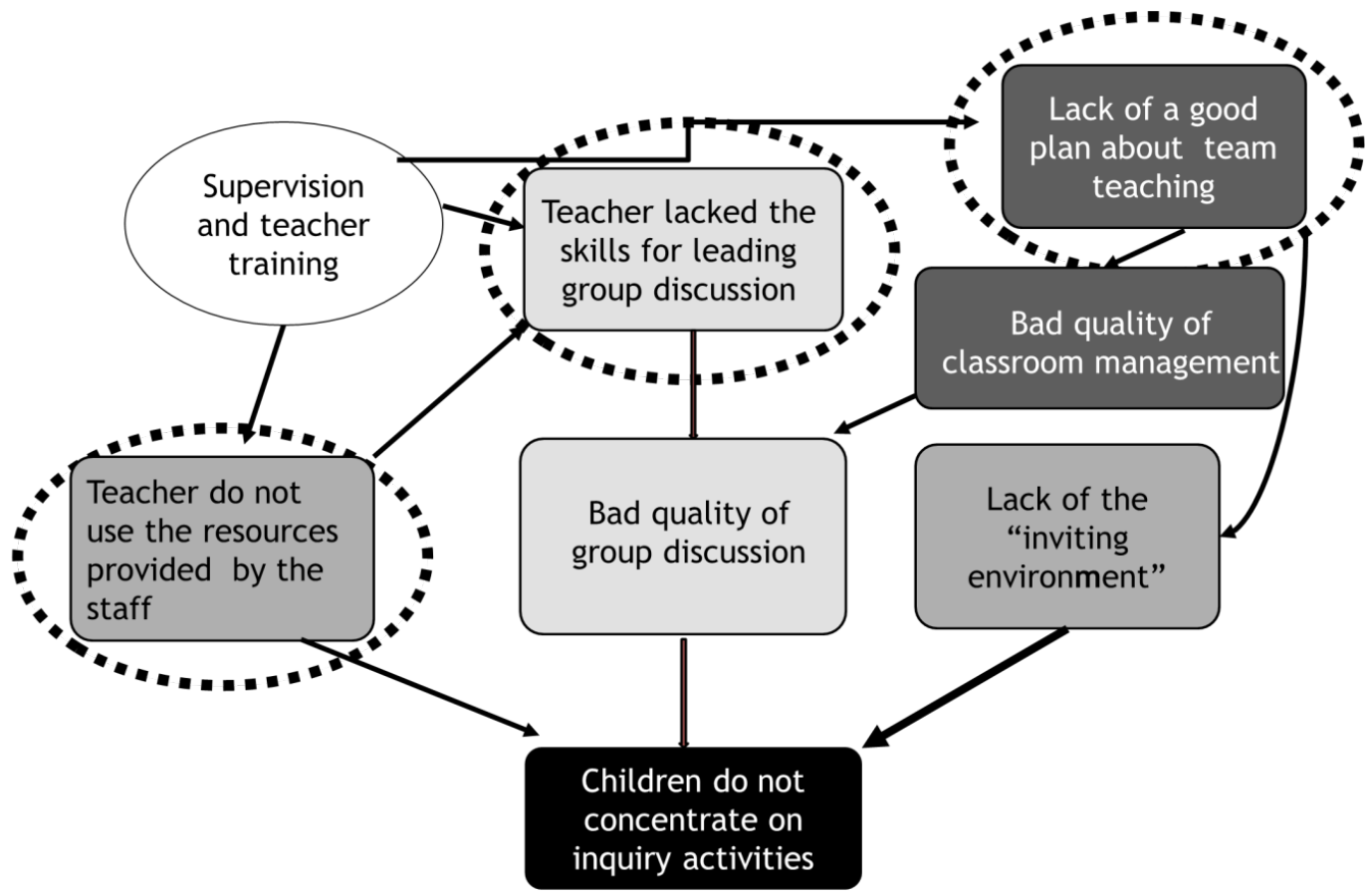

Figure 3: Group teachers expanded solutions on a teacher's instruction barrier.

\section{Discussion}

Two studies were conducted to examine how teacher training program based on situated learning framework would more effectively help teachers to develop themselves professionally. Across the two studies the author used two different approaches as cognitive apprenticeship and community of practices in implementing teacher training programs. The results suggest that both programs may aid learning by engaging in constructivist instruction by providing external supports such as model instruction plans, mentoring, cooperating to solve problems. However, such a professional development program was also found that the relationship or power hierarchy between mentors and learners could play a crucial role in cultivating novices' capabilities. This suggests that practices, sharing on solving problems, rather than superior expertise and diagnosis, may have been the key factor in aiding teacher training in the present studies.

Community of practices approach is not perfect for in-service teacher training. First, community members share their experiences and knowledge in free-flowing, creative ways that foster effective approaches to problems (Wenger \& Snyder, 2000). They would spend much time clarifying and discussing before reaching an agreement on possible solutions. On the contrary, the benefit of cognitive apprenticeship approach is cost effective. Because of supervi- 
sion authority and power, the mentors regularly monitor teachers' instruction and provided suggestions for instruction improvement. Secondly, community of practices approach inherits the managerial paradox which is building and sustaining groups exempt from supervision and interference within large organization (Wenger \& Snyder, 2000). How to integrate them with the rest of an organization will be a challenge.

\section{Conclusions}

This study explored the relationship between mentors and learners in kindergartens with different approaches of professional development. These initial research results served to highlight a number of practical issues, such as motivation, mutual-supports, and supervision, that need to be systematically addressed in future studies. In order to fully understand the advantages of in-service teacher training models, more studies are needed to examine other possible implementations of situated learning for a variety of teachers' experiences and organizations' structures.

\section{References}

Barab, S. A., \& Duffy, T. M. (2000). From practice fields to communities of practice. In D. H. Jonassen \& S. M. Land (Eds.), Theoretical foundations of learning environments (pp. 25-55). Hillsdale, NJ: Lawrence Erlbaum Associates, Inc.

Bell, B., \& Gilbert, J. (1996). Teacher development: A model from science education. London: Falmer Press.

Brown, J. S., \& Duguid, P. (1996). Stolen knowledge. In H. McClellan (Ed.), Situated learning perspectives: The conversation commences (pp. 47-56). Englewood Cliffs, NJ: Educational Technology Publications.

Buysse, V., Sparkman, K. L., \& Wesley, P. W. (2003). Communities of practice: Connecting what we know with what we do. Exceptional Children, 69 (3), 263-277.

Cohan, A., \& Honigsfeld, A. (2011). Breaking the mold of pre-service and in-service teacher education. Maryland: Rowman \& Littlefield Education.

Collins, A., Brown, J. S., \& Newman, S. (1989). Cognitive apprenticeship: Teaching the craft of reading, writing and mathematics. In L. B. Resnick (Ed.), Knowing, learning and instruction: Essays in honor of Robert Glaser (pp. 453-494). Hillsdale, NJ: Lawrence Erlbaum.

Dunlap, J. C. (2005). Problem-based learning and self-efficacy: How a capstone course prepares students for a profession. Educational Technology Research and Development, 53 (1), 65-85.

Gallimore, R., \& Tharp, R. (1990). Teaching mind in society: Teaching, schooling, and literate discourse. In L. C. Moll (Ed.), Vygotsky and Education: Instructional Implications and Applications of Sociohistorical Psychology (pp. 175-205). Cambridge: Cambridge University Press.

Hoban, G. F. (2005). Developing a multi-linked conceptual framework for teacher education design. In G. F. Hoban (Ed.), The Missing Links in Teacher Education Design: Developing a Multi-linked Conceptual Framework (pp. 1-16). Netherland: Springer.

Huang, K. H. (2011). Learning in authentic contexts: Projects integrating spatial technologies and fieldwork. Journal of Geography in Higher Education, 35 (4), 565-578.

Jarvela, S. (1995). The cognitive apprenticeship model in a technologically rich learning environment: Interpreting the learning interaction. Learning and Instruction, 5, 237-259.

Kram, K. (1985). Mentoring at Work: Developmental Relationships in Organization Life. Glenview, IL: Scott, Foresman.

Lave, J. (1993). The practice of learning. In S. Chaiklin \& J. Lave (Eds.), Understanding practice: Perspectives on activity and context (pp. 3-32). New York: Cambridge University Press.

Lave, J., \& Wenger, E. (1991). Situated learning: Legitimate peripheral participation. New York: Cambridge University Press. 
Ching-Ching CHENG. Situated Learning and Professional Development: A Case Study of Applying Cognitive Apprenticeship and Community of Practices in a Kindergarten

PROBLEMS

OF EDUCATION

IN THE $21^{\text {st }}$ CENTURY

Volume 59, 2014

24

Megginson, D., Clutterbuck, D., Garvey, B., Stokes, B., \& Gareet-Harris, R. (2006). Mentoring in Action: A Practical Guide for Managers. London: Kogan Page.

Resnick, L. B. (1987). Learning in school and out. Educational Researcher, 16, 13-20.

Wenger, E. (1998). Communities of practice: Learning, meaning, and identity. New York: Cambridge University Press.

Wenger, E., \& Snyder, W. M. (2000). Communities of Practice: The Organizational Frontier. Harvard Business Review, 78 (1), 139-145.

Wesley, P. W., \& Buysse, V. (2001). Communities of practice: Expanding professional roles to promote reflection and shared inquiry. Topics in Early Childhood Special Education, 21 (2), 114-123.

Advised by Vincentas Lamanauskas, University of Siauliai, Lithuania

Received: December 21, 2013

Accepted: March 28, 2014

Ching-Ching Cheng
Dr., Associate Professor at Institute of Education, Providence University, 200, Sec. 7, Taiwan Boulevard, Shalu Dist., Taichung City 43301, Taiwan.

E-mail: cccheng@pu.edu.tw

Website: http://www.gied.pu.edu.tw 